ISSN 1392-3196 / e-ISSN 2335-8947

Zemdirbyste-Agriculture, vol. 102, No. 3 (2015), p. 273-280

DOI 10.13080/z-a.2015.102.035

\title{
Spring barley stand structure as an indicator of lodging risk
}

\author{
Pavel MATUŠINSKY, Ilona SVOBODOVÁ, Petr MÍŠA \\ Agrotest Fyto, Ltd \\ Havlíčkova 2787, 76701 Kroměříž, Czech Republic \\ E-mail: matusinsky@vukrom.cz
}

\begin{abstract}
Field experiments were performed in Kroměříž, Czech Republic in 2012-2014 and evaluated for spring barley comprising treatments which different sowing rates and nitrogen fertilization rates. The objective of this study was to determine parameters of stand structure in early $(\mathrm{BBCH} 39)$ growth stages of barley that would enable evaluation of lodging risk. Lodging was significantly affected by both year and nitrogen fertilization rate. Increased nitrogen fertilization rates demonstrably increased lodging. Higher fertilization rates manifested in increased tiller biomass weight, greater plant height, and smaller roots. Similarly, the protein content of harvested grain was strongly affected by year and nitrogen application rate. Higher fertilization rates also resulted in grain with higher protein content. Sowing density did not affect either lodging level or protein content. Yields were affected only by year. Increased tiller biomass weight and increased plant height during early growth stages are significant indicators of lodging risk. Correlation between lodging and tiller biomass and plant height was higher than 0.5 and statistically significant $(P=0.000)$.
\end{abstract}

Key words: agronomic practices, Hordeum vulgare, nitrogen fertilization, plant density.

\section{Introduction}

Barley (Hordeum vulgare L.) is the fourth most important cereal crop in the world after wheat, maize, and rice. It is an important crop for direct human consumption as well as for animal fodder. It is an important raw material for producing beer and other products. Barley grain yields and quality can be diminished not only by such biotic and abiotic harmful agents as fungal diseases, low temperatures, and drought, but also as a result of lodging. Lodging occurs in barley when the plant stem is unable to support its own weight. Lodging is often associated with yield loss (Pinthus, 1974). Early lodging can increase moisture in the plant canopy, which adds to the risk of fungal diseases. Early lodging in barley causes the greatest reduction in grain yield potential compared to lodging at later growth stages but also allows higher potential for physical recovery from that lodging (Briggs, 1990). The level of yield loss depends on cultivar, growth stage, and lodging severity (Jedel, Helm, 1991). High levels of soil nitrogen make barley more prone to lodging by inducing more finestemmed tillers, taller growth, greater numbers of grain, and reduced straw strength. Such weather conditions as strong wind or thunderstorm can cause lodging even under good crop management conditions with optimal fertilization and stand density. Two forms of lodging in cereals are known, the first caused by stem fragility and the second by poor root development - thus indicating those factors needing to be adjusted (Ennos, 1991). Plant breeders, have reduced lodging risk by introducing dwarfing genes to produce shorter varieties (Chen et al., 2013; Kuczyńska et al., 2013; Ren et al., 2014) and by increasing stem strength (Ma, 2009), e.g., by higher starch accumulation (Kashiwagi et al., 2006). Structural carbohydrates (cellulose and lignin) should also play an important role for stem strength (Ma, 2009). Farmers employ a range of methods to reduce lodging, the most common of which is the use of plant growth regulators to shorten stems. Other lodging-preventing methods that are less commonly used include reducing seed rate, delaying sowing, reducing and delaying nitrogen application, and rolling the soil (Scott et al., 2005; Berry et al., 2007).

The objective of this study was to determine parameters of stand structure in early (BBCH 39) growth stages of barley that would enable evaluation of lodging risk. Determination of significant indicators of lodging risk appropriate for diagnostic of stand structure parameters could be important part of a decision support system of barley growing strategies. Early decision support system based on relatively cheap measurement of stand parameters could prevent among others fungal infection of cereal heads.

\section{Material and methods}

Field experiment. Field experiments were performed in Kroměříž, Czech Republic in 2012-2014 and evaluated for spring barley comprising treatments which different sowing rates and nitrogen fertilization rates. A small-plot field experiment with a plot size of $10 \mathrm{~m}^{2}$ was established using the variety 'Bojos', which is less resistant to lodging. The preceding crop was winter wheat. Sowing rates of 2.5, 3.5 and 4.5 million germinable seeds (MGS) $\mathrm{ha}^{-1}$ were selected. Each sowing rate included three levels of nitrogen fertilization: 0,45 and $95 \mathrm{~kg} \mathrm{ha}^{-1} \mathrm{~N}$. These 
combinations thus encompassed a total of nine treatments. Fertilization was prior to sowing and using ammonium nitrate with limestone. The combination of different rates of sowing and nitrogen fertilization created the conditions for establishing various morphological and anatomical stem types (different stem types in terms of height and strength) and stand density in individual treatments. Experiments were set up in Kroměříž, Czech Republic $\left(49^{\circ} 17^{\prime} \mathrm{N}\right.$, $17^{\circ} 22^{\prime} \mathrm{E}, 235 \mathrm{~m}$ a.s.1.), which is a beet-growing area. Soil type is Luvic Chernozem (classification: silt earth), mean annual temperature is $9.2^{\circ} \mathrm{C}$, and mean annual rainfall is $576 \mathrm{~mm}$.

Sampling and assessment. Productive tillers were counted during the stage of flag leaf ligule emergence (BBCH 39). Fresh weight and dry weight were determined separately for productive and non-productive tillers as was stand height. Productive tillers' proportion of dry weight was determined, and the fresh weight and dry weight of one productive tiller were calculated. Prior to harvest, the number of ears per $\mathrm{m}^{2}$ was determined. At full maturity, grain yield, 1,000 kernel weight, and grain protein content were determined. Stand lodging was evaluated using European and Mediterranean Plant Protection Organization standard PP 1/144(3). For each plot, the percentage size of the area lodged and lodging intensity as the stem's divergence from vertical in tens of degrees were determined. The lodging index was acquired by multiplying these values and dividing them by 100 .

Statistical analysis. Software STATISTICA was used for statistical processing. Analysis of variance was carried out based on differences among measured parameters. Similar results were obtained using $\log 10$ transformation, and data are therefore displayed untransformed. The relationship between the lodging index and monitored stand characteristics was evaluated by correlation coefficient as calculated in STATISTICA.

\section{Results and discussion}

Lodging resistance in cereals is determined by both genetic and environmental factors (Verma et al.,
2005). Many authors have observed that lodging resistance of barley is affected by the physical and morphological properties of the stem (Chen et al., 2014). Another important factor affecting lodging resistance is stand structure. In the present study, important stand structure parameters were determined, their dependence on experimental factors ascertained, and their relationships with lodging examined. The morphological, physical, and chemical characteristics of stems have been studied by a number of authors in connection with wheat and barley varieties' lodging resistance (Zuber et al., 1999; Berry et al., 2000; 2003; Jeżowski et al., 2000). Various methods have been used to artificially induce lodging, such as dragging weights across the land (Navabi et al., 2006) and using an aerodynamic tunnel (Sterling et al., 2003). Instruments have been developed to measure stem resistance to lateral pressure simulating blasts of wind and rain (Berry et al., 2003). In this study, we analysed field trials under natural conditions without any artificial wind or rain.

In the present study, year was the factor having the largest effect on individual monitored parameters. Year substantially affected the number of ears as well as the number of productive and unproductive tillers and their fresh and dry weights. Year also had a significant effect on lodging, yield, 1,000 kernel weight and protein content (Tables 1-4). The only parameter not affected by year was plant height. The humidity and temperature conditions during 2011-2014 are shown in a climate diagram according to Walter and Lieth (1967) (Fig. 1). The ratio of total precipitation per month to mean monthly temperatures in the climate diagram for Central Europe and the Czech Republic is 3:1. Times when the precipitation curve fell below the temperature curve indicate periods of drought, and vice versa. The climate diagram shows that barley growing season in 2012 was predominantly dry, while in 2014 it was predominantly wet.

Precipitation in June 2012 supported the growth of weak secondary tillers. Some developed productive ears, but these were short with few kernels. The number of productive tillers estimated at $\mathrm{BBCH} 39$ was therefore

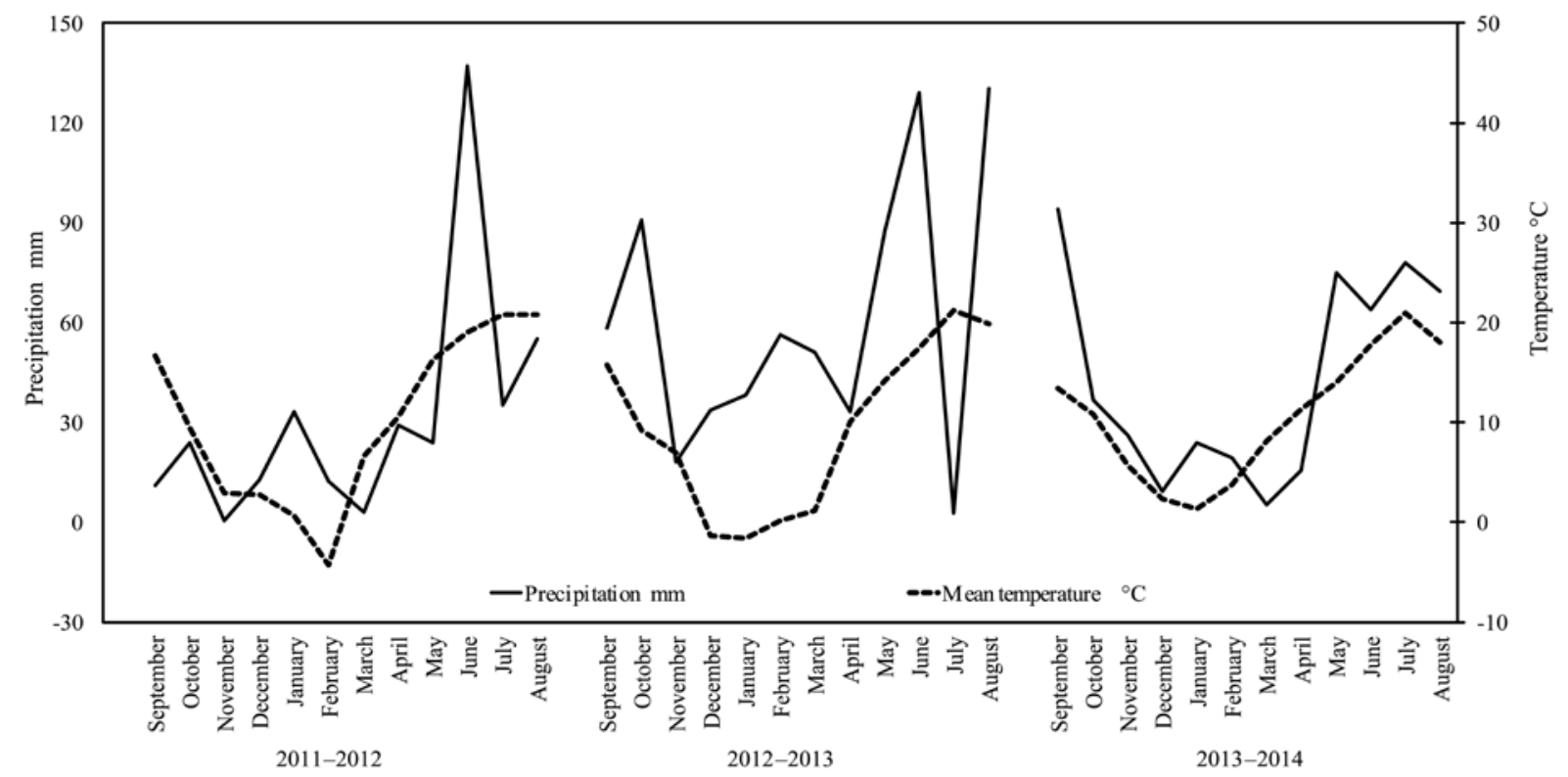

Figure 1. Climate diagram for 2011-2014 at Kroměříž, Czech Republic 
lower than was the number of ears actually formed. July 2012 was a very hot and dry month, with $48 \%$ of the long-term mean precipitation. Treatments with higher nitrogen fertilization rates displayed uneven maturation. There were several storms during June and July, but they did not include both strong wind and heavy precipitation, which otherwise could have caused stand lodging. There was therefore no stand lodging in any treatment in 2012. The most ears, highest yield, and highest protein content were determined in 2012 in comparison to 2013 and 2014 (Tables 1-4).

Table 1. Analysis of variance and Tukey's test $(P<0.05)$ for plant height, number of ears, number of productive tillers and fresh weight of productive tillers at various levels of experimental factors

\begin{tabular}{|c|c|c|c|c|c|c|c|c|c|c|c|c|c|}
\hline \multirow{2}{*}{ Factor } & \multirow{2}{*}{$\begin{array}{c}\text { Factor } \\
\text { level }\end{array}$} & \multicolumn{3}{|c|}{ Plant height } & \multicolumn{3}{|c|}{ Number of ears } & \multicolumn{3}{|c|}{$\begin{array}{l}\text { Number of } \\
\text { productive tillers }\end{array}$} & \multicolumn{3}{|c|}{$\begin{array}{l}\text { Fresh weight of } \\
\text { productive tillers }\end{array}$} \\
\hline & & $\begin{array}{c}\text { mean } \\
\mathrm{cm}\end{array}$ & $F$-stat & $p$-value & mean & $F$-stat & $p$-value & mean & $F$-stat & $p$-value & $\begin{array}{c}\text { mean } \\
\mathrm{g}\end{array}$ & $F$-stat & $p$-value \\
\hline \multirow{3}{*}{ Year } & 2012 & $57.68 \mathrm{a}$ & & & $1077.69 \mathrm{c}$ & & & $765.33 \mathrm{a}$ & & & $2494.79 \mathrm{a}$ & & \\
\hline & 2013 & $56.25 \mathrm{a}$ & 1.847 & 0.1629 & $709.56 \mathrm{a}$ & 50.318 & 0.0000 & $844.44 \mathrm{a}$ & 19.477 & 0.0000 & $3632.22 \mathrm{~b}$ & 42.374 & 0.0000 \\
\hline & 2014 & $59.10 \mathrm{a}$ & & & $947.72 b$ & & & $1014.67 \mathrm{~b}$ & & & $4264.11 \mathrm{c}$ & & \\
\hline \multirow{3}{*}{$\begin{array}{c}\mathrm{N} \\
\text { level }\end{array}$} & 0 & $50.50 \mathrm{a}$ & & & $832.00 \mathrm{a}$ & & & $793.33 \mathrm{a}$ & & & $2920.08 \mathrm{a}$ & & \\
\hline & 45 & $59.94 \mathrm{~b}$ & 114.740 & 0.0000 & $915.64 \mathrm{ab}$ & 4.806 & 0.0101 & $892.00 \mathrm{ab}$ & 5.305 & 0.0064 & $3519.79 \mathrm{~b}$ & 9.098 & 0.0002 \\
\hline & 90 & $62.58 \mathrm{c}$ & & & $987.33 \mathrm{~b}$ & & & $939.11 \mathrm{~b}$ & & & $3951.25 \mathrm{~b}$ & & \\
\hline \multirow{3}{*}{ MGS } & 2.5 & $57.42 \mathrm{a}$ & & & $894.28 \mathrm{a}$ & & & $887.56 \mathrm{a}$ & & & $3444.78 \mathrm{a}$ & & \\
\hline & 3.5 & $57.58 \mathrm{a}$ & 0.087 & 0.9170 & $898.00 \mathrm{a}$ & 0.533 & 0.5884 & $864.44 \mathrm{a}$ & 0.12 & 0.8872 & $3442.27 \mathrm{a}$ & 0.035 & 0.9653 \\
\hline & 4.5 & $58.03 \mathrm{a}$ & & & $942.69 \mathrm{a}$ & & & $872.44 \mathrm{a}$ & & & $3504.08 \mathrm{a}$ & & \\
\hline
\end{tabular}

Nitrogen level $=\mathrm{kg} \mathrm{ha}^{-1} \mathrm{~N} ; \mathrm{MGS}-$ sowing rate at million germinable seeds; $\mathrm{N}=36$

Table 2. Analysis of variance and Tukey's test $(P<0.05)$ for dry weight of productive tillers, fresh and dry weight of nonproductive tillers and productive tillers' proportion of dry weight at various levels of experimental factors

\begin{tabular}{|c|c|c|c|c|c|c|c|c|c|c|c|c|c|}
\hline \multirow{2}{*}{ Factor } & \multirow{2}{*}{$\begin{array}{c}\text { Factor } \\
\text { level }\end{array}$} & \multicolumn{3}{|c|}{$\begin{array}{l}\text { Dry weight of } \\
\text { productive tillers }\end{array}$} & \multicolumn{3}{|c|}{$\begin{array}{c}\text { Fresh weight of } \\
\text { nonproductive tillers }\end{array}$} & \multicolumn{3}{|c|}{$\begin{array}{c}\text { Dry weight of } \\
\text { nonproductive tillers }\end{array}$} & \multicolumn{3}{|c|}{$\begin{array}{l}\text { Productive tillers' proportion } \\
\text { of dry weight }\end{array}$} \\
\hline & & $\underset{\mathrm{g}}{\operatorname{mean}}$ & $F$-stat & $p$-value & $\begin{array}{c}\text { mean } \\
\mathrm{g}\end{array}$ & $F$-stat & $p$-value & $\begin{array}{c}\text { mean } \\
\%\end{array}$ & $F$-stat & $p$-value & $\begin{array}{c}\text { mean } \\
\mathrm{g}\end{array}$ & $F$-stat & $p$-value \\
\hline \multirow{3}{*}{ Year } & 2012 & $433.91 \mathrm{a}$ & & & $411.92 \mathrm{~b}$ & & & $63.96 \mathrm{c}$ & & & $17.37 \mathrm{~b}$ & & \\
\hline & 2013 & $489.18 \mathrm{a}$ & 164.839 & 0.0000 & $441.28 \mathrm{~b}$ & 17.863 & 0.0000 & $53.57 \mathrm{~b}$ & 34.81 & 0.0000 & $13.52 \mathrm{a}$ & 303.53 & 0.0000 \\
\hline & 2014 & $886.61 \mathrm{~b}$ & & & $291.24 \mathrm{a}$ & & & $36.35 \mathrm{a}$ & & & $21.41 \mathrm{c}$ & & \\
\hline \multirow{3}{*}{$\begin{array}{c}\mathrm{N} \\
\text { level }\end{array}$} & 0 & $551.01 \mathrm{a}$ & & & $335.28 \mathrm{a}$ & & & $47.78 \mathrm{a}$ & & & $18.65 \mathrm{c}$ & & \\
\hline & 45 & $611.43 \mathrm{a}$ & 1.557 & 0.2156 & $376.17 \mathrm{ab}$ & 5.767 & 0.0043 & $50.41 \mathrm{a}$ & 1.79 & 0.1724 & $17.25 \mathrm{~b}$ & 25.03 & 0.0000 \\
\hline & 90 & $647.26 \mathrm{a}$ & & & $432.99 \mathrm{~b}$ & & & $55.69 \mathrm{a}$ & & & $16.41 \mathrm{a}$ & & \\
\hline \multirow{3}{*}{ MGS } & 2.5 & $607.00 \mathrm{a}$ & & & $335.94 \mathrm{a}$ & & & $47.30 \mathrm{a}$ & & & $17.82 \mathrm{a}$ & & \\
\hline & 3.5 & $598.10 \mathrm{a}$ & 0.0136 & 0.9865 & $376.98 \mathrm{ab}$ & 5.289 & 0.0066 & $49.18 \mathrm{ab}$ & 3.27 & 0.0422 & $17.35 \mathrm{a}$ & 2.40 & 0.0958 \\
\hline & 4.5 & $604.59 \mathrm{a}$ & & & $431.52 \mathrm{~b}$ & & & $57.40 \mathrm{~b}$ & & & $17.13 \mathrm{a}$ & & \\
\hline
\end{tabular}

Nitrogen level $=\mathrm{kg} \mathrm{ha}^{-1} \mathrm{~N} ; \mathrm{MGS}-$ sowing rate at million germinable seeds; $\mathrm{N}=36$

Table 3. Analysis of variance and Tukey's test $(P<0.05)$ for fresh and dry weight of one productive tiller and lodging at various levels of experimental factors

\begin{tabular}{|c|c|c|c|c|c|c|c|c|c|c|}
\hline \multirow{2}{*}{ Factor } & \multirow{2}{*}{$\begin{array}{c}\text { Factor } \\
\text { level }\end{array}$} & \multicolumn{3}{|c|}{$\begin{array}{c}\text { Fresh weight of } \\
\text { one productive tiller }\end{array}$} & \multicolumn{3}{|c|}{$\begin{array}{c}\text { Dry weight of } \\
\text { one productive tiller }\end{array}$} & \multicolumn{3}{|c|}{ Lodging } \\
\hline & & $\begin{array}{l}\text { mean } \\
\mathrm{t} \mathrm{ha}^{-1}\end{array}$ & $F$-stat & $p$-value & $\begin{array}{c}\text { mean } \\
\mathrm{g}\end{array}$ & $F$-stat & $p$-value & $\begin{array}{c}\text { mean } \\
\%\end{array}$ & $F$-stat & $p$-value \\
\hline \multirow{3}{*}{ Year } & 2012 & $3.26 \mathrm{a}$ & \multirow{3}{*}{122.12} & \multirow{3}{*}{0.0000} & $0.57 \mathrm{a}$ & \multirow{3}{*}{298.11} & \multirow{3}{*}{0.0000} & $0.00 \mathrm{a}$ & \multirow{3}{*}{36.035} & \multirow{3}{*}{0.0000} \\
\hline & 2013 & $4.28 \mathrm{~b}$ & & & $0.58 \mathrm{~b}$ & & & $22.89 \mathrm{~b}$ & & \\
\hline & 2014 & $4.18 \mathrm{~b}$ & & & $0.89 \mathrm{c}$ & & & $34.21 \mathrm{c}$ & & \\
\hline \multirow{3}{*}{$\begin{array}{c}\mathrm{N} \\
\text { level }\end{array}$} & 0 & $3.67 \mathrm{a}$ & \multirow{3}{*}{21.51} & \multirow{3}{*}{0.0000} & $0.69 \mathrm{a}$ & \multirow{3}{*}{0.84} & \multirow{3}{*}{0.4359} & $4.61 \mathrm{a}$ & \multirow{3}{*}{20.662} & \multirow{3}{*}{0.0000} \\
\hline & 45 & $3.92 \mathrm{~b}$ & & & $0.67 \mathrm{a}$ & & & $18.79 \mathrm{~b}$ & & \\
\hline & 90 & $4.14 \mathrm{c}$ & & & $0.67 \mathrm{a}$ & & & $33.69 \mathrm{c}$ & & \\
\hline \multirow{3}{*}{ MGS } & 2.5 & $3.85 \mathrm{a}$ & \multirow{3}{*}{0.91} & \multirow{3}{*}{0.4070} & $0.68 \mathrm{a}$ & \multirow{3}{*}{0.41} & \multirow{3}{*}{0.6633} & $17.35 \mathrm{a}$ & \multirow{3}{*}{0.661} & \multirow{3}{*}{0.5184} \\
\hline & 3.5 & $3.93 \mathrm{a}$ & & & $0.68 \mathrm{a}$ & & & $17.18 \mathrm{a}$ & & \\
\hline & 4.5 & $3.94 \mathrm{a}$ & & & $0.67 \mathrm{a}$ & & & $22.57 \mathrm{a}$ & & \\
\hline
\end{tabular}

Nitrogen level $=\mathrm{kg} \mathrm{ha}^{-1} \mathrm{~N} ; \mathrm{MGS}-$ sowing rate at million germinable seeds; $\mathrm{N}=36$ 
Table 4. Analysis of variance and Tukey's test $(P<0.05)$ for yield, 1,000 kernel weight and protein content at various levels of experimental factors

\begin{tabular}{|c|c|c|c|c|c|c|c|c|c|c|}
\hline \multirow[b]{2}{*}{ Factor } & \multirow{2}{*}{$\begin{array}{c}\text { Factor } \\
\text { level }\end{array}$} & \multicolumn{3}{|c|}{ Yield } & \multicolumn{3}{|c|}{1,000 kernel weight } & \multicolumn{3}{|c|}{ Protein content } \\
\hline & & $\begin{array}{c}\text { mean } \\
\mathrm{t} \mathrm{ha}^{-1}\end{array}$ & $F$-stat & $p$-value & $\begin{array}{c}\text { mean } \\
\mathrm{g}\end{array}$ & $F$-stat & $p$-value & $\begin{array}{c}\text { mean } \\
\%\end{array}$ & $F$-stat & $p$-value \\
\hline \multirow{3}{*}{ Year } & 2012 & $6.73 \mathrm{~b}$ & \multirow{3}{*}{16.72} & \multirow{3}{*}{0.0000} & $44.79 \mathrm{a}$ & \multirow{3}{*}{94.840} & \multirow{3}{*}{0.0000} & $13.69 \mathrm{c}$ & \multirow{3}{*}{48.081} & \multirow{3}{*}{0.0000} \\
\hline & 2013 & $5.94 \mathrm{a}$ & & & $49.60 \mathrm{~b}$ & & & $13.02 \mathrm{~b}$ & & \\
\hline & 2014 & $6.65 \mathrm{~b}$ & & & $50.06 \mathrm{~b}$ & & & $11.70 \mathrm{a}$ & & \\
\hline \multirow{3}{*}{$\begin{array}{c}\mathrm{N} \\
\text { level }\end{array}$} & 0 & $6.19 \mathrm{a}$ & \multirow{3}{*}{1.383} & \multirow{3}{*}{0.1377} & $49.01 \mathrm{~b}$ & \multirow{3}{*}{8.691} & \multirow{3}{*}{0.0019} & $12.04 \mathrm{a}$ & \multirow{3}{*}{28.870} & \multirow{3}{*}{0.0000} \\
\hline & 45 & $6.61 \mathrm{a}$ & & & $48.19 \mathrm{ab}$ & & & $12.76 \mathrm{~b}$ & & \\
\hline & 90 & $6.52 \mathrm{a}$ & & & $47.25 \mathrm{a}$ & & & $13.61 \mathrm{c}$ & & \\
\hline \multirow{3}{*}{ MGS } & 2.5 & $6.42 \mathrm{a}$ & \multirow{3}{*}{0.589} & \multirow{3}{*}{0.5566} & $48.91 \mathrm{~b}$ & \multirow{3}{*}{5.962} & \multirow{3}{*}{0.0093} & $12.62 \mathrm{a}$ & \multirow{3}{*}{1.231} & \multirow{3}{*}{0.3134} \\
\hline & 3.5 & $6.36 \mathrm{a}$ & & & $48.08 \mathrm{ab}$ & & & $12.93 \mathrm{a}$ & & \\
\hline & 4.5 & $6.54 \mathrm{a}$ & & & $47.46 \mathrm{a}$ & & & $12.86 \mathrm{a}$ & & \\
\hline
\end{tabular}

Nitrogen level $=\mathrm{kg} \mathrm{ha}^{-1} \mathrm{~N}$; MGS - sowing rate at million germinable seeds

In 2013, a cold March caused a delay in sowing. Snow still covered the fields at the beginning of April. At the time of stem elongation, the cold and rainy weather supported rapid growth of plant matter with not very strong stem walls and shallow, thin roots. Root lodging occurred on 23 and 24 June 2013 during intense, short rainfall. According to data from a meteorological station $800 \mathrm{~m}$ distant, between 20 and 24 June 2013 there was a total of $65 \mathrm{~mm}$ of rainfall and soil humidity at $10 \mathrm{~cm}$ reached $31.9 \%$. At that time, plants were in $\mathrm{BBCH} 71$ stage when the first grains had reached their final size and grain content was watery. Stem lodging did not occur. In the following period, stems rose through growth from one side of their nodes. In mid-July, the plants were still milky ripe as a result of the delayed sowing. July 2013 was extraordinarily dry with rainfall of only $2.7 \mathrm{~mm}$, i.e. $4 \%$ of the long-term mean, and was also very hot. Grains withered away in a number of ears, and so the actual number of ears was lower than the number of productive tillers. Drying occurred mainly with weak productive tillers in the low and medium sowing rate treatments (the most drying occurred at the sowing rate of 2.5 MGS $\mathrm{ha}^{-1}$ with no $\mathrm{N}$ application and the sowing rate of 3.5 MGS ha ${ }^{-1}$ with $90 \mathrm{~kg} \mathrm{ha}^{-1} \mathrm{~N}$ ). Dry and hot weather in the second half of July accelerated grain ripening. The lowest number of ears and lowest grain yields over the entire experiment were measured in 2013.

The winter of 2013-2014 was mild, and aboveaverage temperatures in March along with little rainfall enabled early sowing. A longer germination period was caused by dry weather, as rainfall in March 2014 was $16 \%$ of the long-term mean. During tillering in April, rainfall was low and evenly distributed, which supported root system growth. Higher rainfall in May along with lower temperatures during stem elongation enabled rapid growth of plant matter with not very strong stem walls and decreased tiller reduction. There were many productive stems. In lower density stands, particularly those with a sowing rate of $2.5 \mathrm{MGS} \mathrm{ha}^{-1}$, additional productive tillers were produced. Grain initially formed under advantageous temperature and humidity conditions, and despite predominantly dry and hot weather during 11-20 July 2014 grain weight and therefore yield remained at a relatively good level. Lodging occurred as milky ripe became waxy ripe on 29 June 2014 during storms with heavy rain accompanied by wind. In the following period, the stems rose through growth from one side of the node at the uppermost internode below the ear. Grain ripened early during above-average temperatures in July 2014. The highest lodging level and lowest grain protein content over the entire experiment were measured in 2014.

Another factor substantially affecting the monitored stand parameters in our experiment was nitrogen fertilization level. Previous studies have shown that high $\mathrm{N}$ application leads to thinner stems and significant increases in lodging of wheat (Kong et al., 2014) and rice (Yang et al., 2009). Although the content of cellulose or lignin is related to stem rigidity (Taylor et al., 1999; Jones et al., 2001), the relationship between cellulose or lignin content and lodging resistance has not been clear. Stalk strength in previous work with maize significantly negatively correlates with lodging observed in the field ( $\mathrm{Hu}$ et al., 2012). Application of abundant nitrogen at the ripening stage increases the accumulation of carbohydrates in stems and improves lodging resistance, but it also reduces cellulose content (Matsuzaki et al., 1972). By comparing fertilization rates and lodging within our experiment, it was determined that increasing fertilization rates $\left(0,45\right.$ and $\left.90 \mathrm{~kg} \mathrm{ha}^{-1}\right)$ demonstrably increased plant height, number of ears, weight of one productive tiller, number and fresh weight of productive tillers, and grain protein content (Fig. 2), but also lodging level (Tables 1-4, Fig. 3). In contrast, productive tillers' proportion of dry weight decreased with increasing fertilization rates.

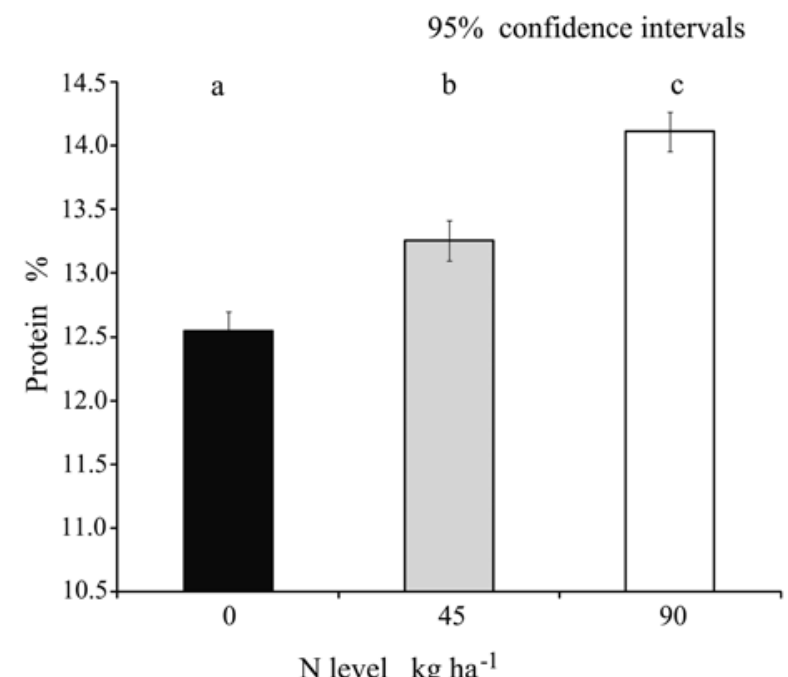

Figure 2. Barley grain protein content at various nitrogen fertilization levels (2012-2014) 


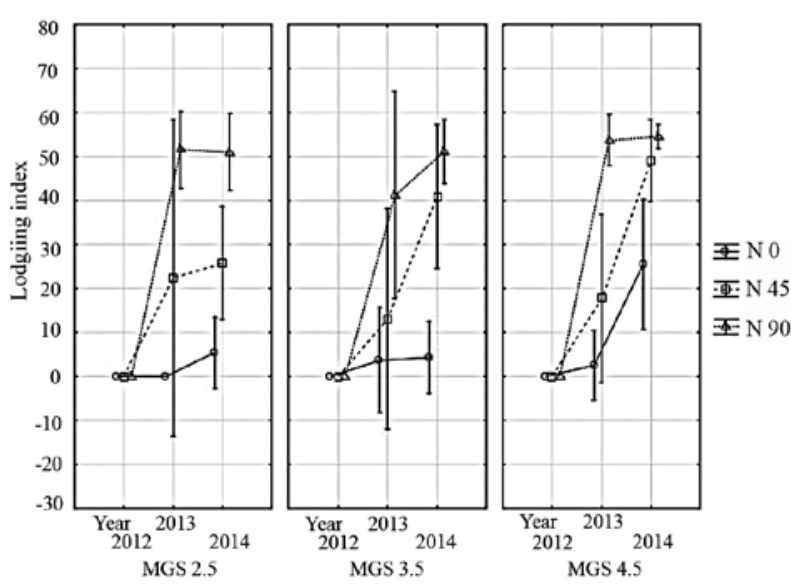

MGS - sowing rate at million germinable seeds

Figure 3. Spring barley lodging index in various years at various sowing and nitrogen fertilization $\left(\mathrm{kg} \mathrm{ha}^{-1}\right)$ rates

In stems, higher accumulation of starch contributes to greater bending strength (Matsuzaki et al., 1972). Such results suggest that higher contents of carbohydrates accumulated in lower stems might enhance the bending strength of the basal stem and, as a consequence, cause higher lodging resistance. In addition to resistance in stems, roots also are affected by fertilization rates. With increasing sowing rate at fertilization rates 0 and $45 \mathrm{~kg}$ $\mathrm{ha}^{-1}$, roots shorten and weaken due to competition and fewer tillers with adventitious roots are produced. The effect of sowing rate is clearly visible for fertilization rate $90 \mathrm{~kg} \mathrm{ha}^{-1}$, where for lower sowing rates there is not such competition for resources as there is at higher sowing rates, which therefore result in longer and narrower root bundles. The effect of nitrogen is more noticeable at the lowest sowing rate where plants are further apart and there is therefore less competition for space. Roots were deeper in the treatments without nitrogen fertilization at sowing rates 2.5 and 3.5 $\mathrm{MGS} \mathrm{ha}^{-1}$ in comparison to the treatments fertilized with nitrogen. In the absence of fertilization, roots must grow deeper to acquire more nitrogen from the soil. At fertilization rate of $90 \mathrm{~kg} \mathrm{ha}^{-1}$ and sowing rates 2.5 and $3.5 \mathrm{MGS} \mathrm{ha}^{-1}$, sufficient nitrogen and little competition among plants meant roots did not need to grow deeper, and therefore roots in the bundles were shallow. At the highest sowing rate, differences in root density were not visible among fertilization rates; roots were not as deep, but root bundles grew more sparsely and weaker (data not shown). Generally, with increasing fertilization rates roots shortened and weakened and root bundles narrowed, while with increasing sowing rates root bundles grew more sparsely and narrower and roots weakened. Crook and Ennos (1994) developed simple equations to investigate lodging phenomena in cereals. These static equations predict a relative degree of susceptibility to anchorage failure and shoot failure, known as root and shoot lodging, respectively. According to Crook and Ennos (1995), lodging susceptibility in cereals depends on three factors: first, the size and dynamics of the forces to which the plant is subjected; second, the bending strength of the shoot and its resistance to buckling; and third, the anchorage strength of the root system. The model was adjusted for barley by Berry et al. (2006).

The factor having the smallest effect on monitored parameters in the current study was sowing rate. Sowing rate had a less considerable effect probably due to a stand's compensatory abilities. As sowing rate increased, the number of ears per $\mathrm{m}^{2}$ slightly increased, but the values of the remaining characteristics rather decreased. Unproductive tillers increased in weight (Tables 1-4). The number and weight of productive tillers were not affected by sowing rate (Fig. 4).

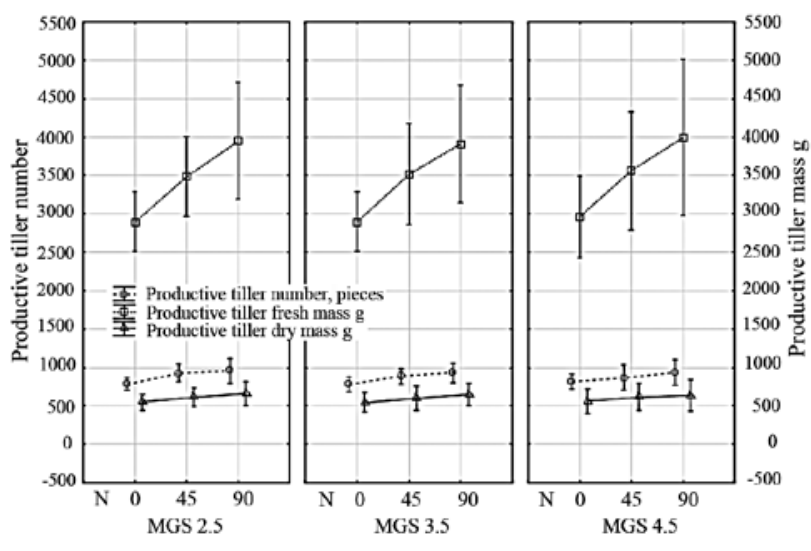

MGS - sowing rate at million germinable seeds

Figure 4. Productive tillers of spring barley at various sowing and nitrogen fertilization $\left(\mathrm{kg} \mathrm{ha}^{-1}\right)$ rates $(2012-$ 2014)

Correlation coefficients higher than 0.5 were determined between lodging and the parameters plant height, fresh weight of productive tillers, and fresh weight of one productive tiller (Table 5, Fig. 5). No correlation with lodging was determined for the remaining parameters. Plant height was the factor with the highest positive correlation coefficient with lodging index. A similarly high positive correlation coefficient was calculated between lodging and fresh weight of productive tillers. Here, the weight and height of plants' above-ground parts were important for stands' lodging resistance. Taller stands with greater productive tiller weight were discernibly more susceptible to lodging. In evaluating factors that can be affected agro-technically, Tables 1-4 make it clear that these parameters (plant height and fresh weight of productive tillers) are affected by fertilization rates. At higher nitrogen levels, plant height and fresh weight of productive tillers increased. Plant height appears to be the major contributor to lodging tolerance (Chen et al., 2013; Kuczyńska et al., 2013; Ren et al., 2014). In previous study, lodging severity in shortstem varieties was very low and no significant variation was observed for yield and lodging scores while plant height was strongly correlated with lodging scores at all growth stages (Navabi et al., 2006).

Barley variety is an important factor. Jeżowski et al. (2000) found that six-rowed, doubled haploid barley lines were characterized by lower elasticity and shorter stems than were two-rowed lines, and six-rowed 
Table 5. Correlation coefficients for lodging and characteristics measured at BBCH 39 stage (2012-2014)

\begin{tabular}{lcc}
\hline \multicolumn{1}{c}{ Factor } & $\begin{array}{c}\text { Correlation } \\
\text { coefficient } \\
(r)\end{array}$ & $p$-value \\
\hline Plant height & $\mathbf{0 . 7 1 0}$ & $\mathbf{0 . 0 0 0 0}$ \\
Number of ears & 0.412 & 0.0003 \\
Yield & 0.135 & 0.2573 \\
Fresh weight of non-productive tillers & 0.167 & 0.1610 \\
Dry weight of non-productive tillers & 0.006 & 0.9593 \\
Number of productive tillers & 0.392 & 0.0007 \\
Fresh weight of productive tillers & $\mathbf{0 . 5 4 6}$ & $\mathbf{0 . 0 0 0 0}$ \\
Dry weight of productive tillers & 0.403 & 0.0004 \\
Productive tillers' proportion of dry weight & -0.002 & 0.9868 \\
Fresh weight of one productive tiller & $\mathbf{0 . 5 6 4}$ & $\mathbf{0 . 0 0 0 0}$ \\
Dry weight of one productive tiller & 0.221 & 0.0619 \\
1,000 kernel weight & 0.452 & 0.0178 \\
Protein content & -0.151 & 0.4502 \\
\hline
\end{tabular}
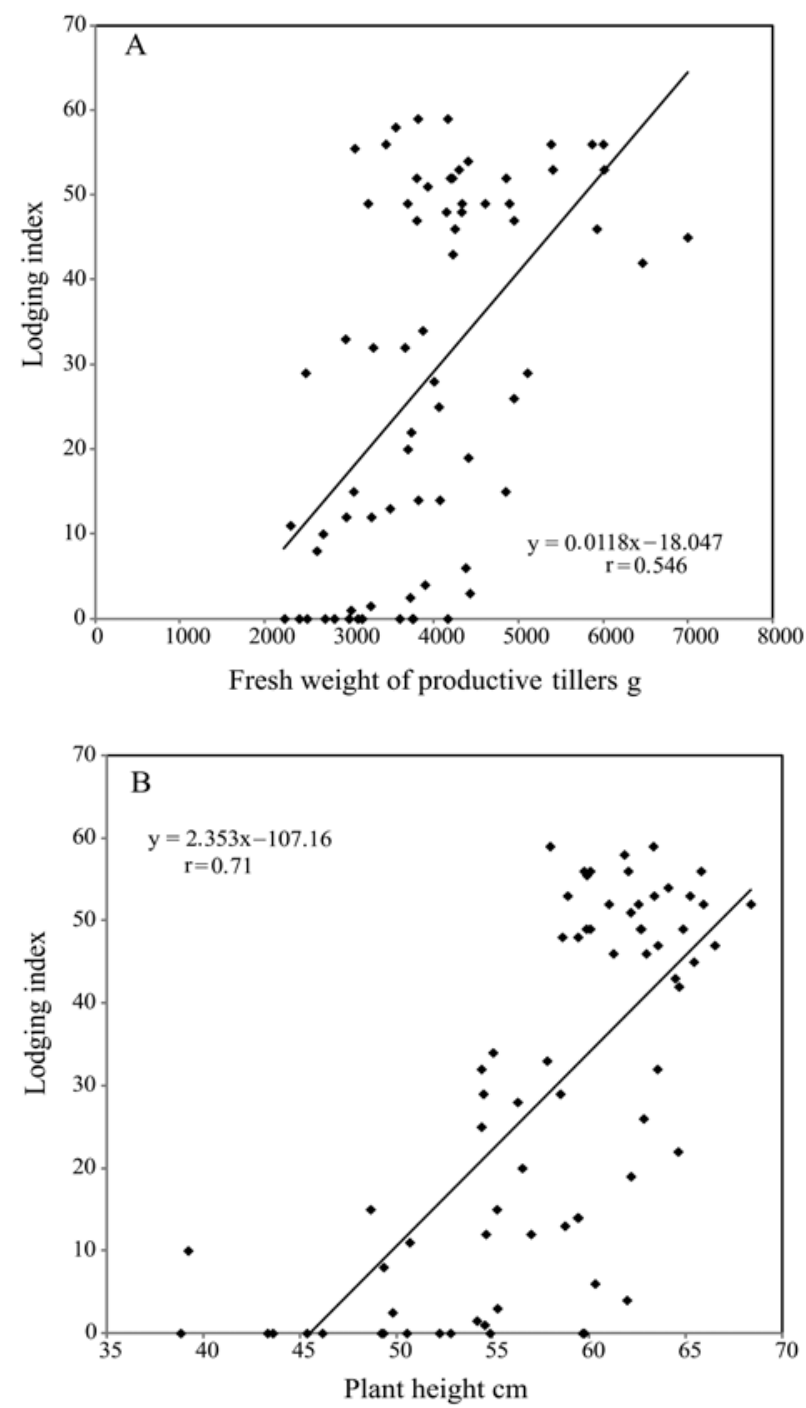

Figure 5. Correlation coefficients of lodging and fresh weight of productive tillers (A) and plant height (B) (2012-2014) lines were more susceptible to lodging. Two- and sixrowed genotypes displayed similar genetic backgrounds of lodging resistance. The effects of additive gene action were important for all morphological and physical stem characteristics, while dominance effects were significant only for stem length and lodging grade (Jeżowski et al., 2000). Previous studies have reported different levels of yield reduction: 21\% (Briggs, 1990), 30\% (Pinthus, 1974), $40 \%$ (Eassen et al., 1993) and up to $66 \%$ (Berry et al., 2003), depending on crop stage at the date of lodging and on lodging intensity. When lodging occurs before elongation, plants are able to recover their upright position, as opposed to when it occurs after heading. In our experiment, yield was affected only by year.

\section{Conclusions}

1. Increased tiller biomass weight and increased plant height during early $(\mathrm{BBCH} 39)$ growth stages are significant indicators of lodging risk. The correlation between lodging and tiller biomass and plant height was higher than 0.5 and statistically significant $(P=0.000)$. Diagnostic of stand structure parameters during early growth stages could be important part of decision support system of barley growing strategies.

2. Lodging was significantly affected both by year and nitrogen fertilization rate. Level of lodging in years from 2012 to 2014 was $0.00,22.89$ and $34.21 \%$, respectively. Increasing nitrogen fertilization rates $(0$, 45 and $90 \mathrm{~kg} \mathrm{ha}^{-1}$ ) significantly increased lodging level (4.61, 18.79 and $33.69 \%$, respectively).

3. Protein content in harvested grain was strongly affected by year and fertilization rate. Grain protein content in years from 2012 to 2014 was $13.69,13.02$ and $11.70 \%$, respectively. Increasing nitrogen fertilization rates $\left(0,45\right.$ and $\left.90 \mathrm{~kg} \mathrm{ha}^{-1}\right)$ significantly increased protein content (12.04, 12.76 and $13.61 \%$, respectively).

4. Sowing rates used in this study $-2.5,3.5$ and 4.5 million germinable seeds (MGS) - had a less considerable effect on lodging due to compensatory abilities of a stand.

5 . Yield was affected only by year. Grain yield in years from 2012 to 2014 was $6.73,5.94$ and $6.65 \mathrm{t} \mathrm{ha}^{-1}$, respectively.

\section{Acknowledgements}

The work was supported by the Ministry of Agriculture of the Czech Republic under projects QJ1210008, QJ1310091 and RO0211.

Received 25022015 Accepted 05082015 


\section{References}

Berry P. M., Griffin J. M., Sylvester-Bradley R., Scott R. K., Spink J. H., Baker C. J., Clare R. W. 2000. Controlling plant form through husbandry to minimise lodging in wheat. Field Crops Research, 67 (1): 59-81 http://dx.doi.org/10.1016/S0378-4290(00)00084-8

Berry P. M., Spink J., Sterling M., Pickett A. A. 2003. Methods for rapidly measuring the lodging resistance of wheat cultivars. Journal of Agronomy and Crop Science, 189 (6): 390-401 http://dx.doi.org/10.1046/j.0931-2250.2003.00062.x

Berry P. M., Sterling M., Mooney S. J. 2006. Development of a model of lodging for barley. Journal of Agronomy and Crop Science, 192 (2): 151-158 http://dx.doi.org/10.1111/j.1439-037X.2006.00194.x

Berry P. M., Sylvester-Bradley R., Berry S. 2007. Ideotype design for lodging-resistant wheat. Euphytica, 154 (1-2): 165-179 http://dx.doi.org/10.1007/s10681-006-9284-3

Briggs K. G. 1990. Studies of recovery from artificially induced lodging in several six-row barley cultivars. Canadian Journal of Plant Science, 70 (1): 173-181 http://dx.doi.org/10.4141/cjps90-019

Chen L., Phillips A. L., Condon A. G., Parry M. A. J., Hu Y. -G. 2013. GA-responsive dwarfing gene Rht12 affects the developmental and agronomic traits in common bread wheat. Plos One, 8 (4): e62285 http://dx.doi.org/10.1371/journal.pone.0062285

Chen W. Y., Liu Z. M., Deng G. B., Pan Z. F., Liang J. J., Zeng X. Q., Tashi N. M., Long H., Yu M. Q. 2014. Genetic relationship between lodging and lodging components in barley (Hordeum vulgare) based on unconditional and conditional quantitative trait locus analyses. Genetics and Molecular Research, 13 (1): 1909-1925 http://dx.doi.org/10.4238/2014.March.17.19

Crook M. J., Ennos A. R. 1994. Stem and root characteristics associated with lodging resistance in four winter wheat cultivars. The Journal of Agricultural Science, 123 (2): 167-174 http://dx.doi.org/10.1017/S0021859600068428

Crook M. J., Ennos A. R. 1995. The effect of nitrogen and growth regulators on stem and root characteristics associated with lodging in two cultivars of winter wheat. Journal of Experimental Botany, 46 (8): 931-938 http://dx.doi.org/10.1093/jxb/46.8.931

Eassen D. L., White E. M., Pickles S. J. 1993. The effects of weather, seed rate and cultivar on lodging and yield in winter wheat. The Journal of Agricultural Science, 121 (2): 145-156 http://dx.doi.org/10.1017/S0021859600077005

Ennos A. R. 1991. The mechanics of anchorage in wheat Triticum aestivum L. II. Anchorage of mature wheat against lodging. Journal of Experimental Botany, 42 (245): 1607-1613 http://dx.doi.org/10.1093/jxb/42.12.1607

Hu H., Meng Y., Wang H., Liu H., Chen S. 2012. Identifying quantitative trait loci and determining closely related stalk traits for rind penetrometer resistance in a high-oil maize population. Theoretical and Applied Genetics, 124 (8):1439-1447

http://dx.doi.org/10.1007/s00122-012-1799-5

Jedel P. E., Helm J. H. 1991. Lodging effects on a semidwarf and two standard barley cultivars. Agronomy Journal, 83 (1): 158-161 http://dx.doi.org/10.2134/agronj1991.00021 962008300010036x
Jeżowski S., Adamski T., Surma M., Krajewski P., LeśniewskaFrączak M. 2000. Variation of some physical and geometrical stem features in doubled haploids of barley. International Agrophysics, 14 (2): 187-189

Jones L., Ennos A. R., Turner S. R. 2001. Cloning and characterization of irregular xylem4 (irx4): a severely lignin-deficient mutant of Arabidopsis. The Plant Journal, 26 (2): 205-216

http://dx.doi.org/10.1046/j.1365-313x.2001.01021.x

Kashiwagi T., Madoka Y., Hirotsu N., Ishimaru K. 2006. Locus prl5 improves lodging resistance of rice by delaying senescence and increasing carbohydrate re-accumulation. Plant Physiology and Biochemistry, 44: 152-157 http://dx.doi.org/10.1016/j.plaphy.2006.02.004

Kong L., Sun M., Wang F., Liu J., Feng B., Si J., Zhang B., Li S., Li H. 2014. Effects of high $\mathrm{NH}^{+4}$ on $\mathrm{K}^{+}$uptake, culm mechanical strength and grain filling in wheat. Frontiers of Plant Science, 5 (703): 1-10 http://dx.doi.org/10.3389/fpls.2014.00703

Kuczyńska A., Surma M., Adamski T., Mikołajczak K., Krystkowiak K., Ogrodowicz P. 2013. Effects of the semidwarfing $s d w 1 /$ denso gene in barley. Journal of Applied Genetics, 54 (4): 381-390 http://dx.doi.org/10.1007/s13353-013-0165-x

Ma Q. H. 2009. The expression of caffeic acid 3-O-methyltransferase in two wheat genotypes differing in lodging resistance. Journal of Experimental Botany, 60 (9): 2763-2771 http://dx.doi.org/10.1093/jxb/erp132

Matsuzaki A., Matsushima S., Tomita T., Katsuki E. 1972. Analysis of yield-determining process and its application to yield-prediction and culture improvement of lowland rice. CIX. Effects of nitrogen top-dressing at full heading stage on lodging resistance, root activity, yield and kernel quality. Japanese Journal of Crop Science, 41 (2): 139-146 http://dx.doi.org/10.1626/jcs.41.139

Navabi A., Iqbal M., Strenzke K., Spaner D. 2006. The relationship between lodging and plant height in a diverse wheat population. Canadian Journal of Plant Science, 86 (3): 723-726 http://dx.doi.org/10.4141/P05-144

Pinthus M. J. 1974. Lodging in wheat, barley and oats: the phenomenon, its causes, and preventative measures. Advances in Agronomy, 25: 209-263 http://dx.doi.org/10.1016/S0065-2113(08)60782-8

Ren X. F., Sun D. F., Dong W. B., Sun G. L., Li C. D. 2014. Molecular detection of QTL controlling plant height components in a doubled haploid barley population. Genetics and Molecular Research, 13 (2): 3089-3099 http://dx.doi.org/10.4238/2014.April.17.5

Scott D. I., Tams A. R., Berry P. M., Mooney S. J. 2005. The effects of wheel induced soil compaction on anchorage strength and resistance to root lodging of winter barley (Hordeum vulgare L.). Soil and Tillage Research, 82: $147-160$ http://dx.doi.org/10.1016/j.still.2004.06.008

Sterling M., Baker C. J., Berry P. M., Wade A. 2003. An experimental investigation of the lodging of wheat. Agriculture and Forest Meteorology, 119 (3-4): 149-165 http://dx.doi.org/10.1016/S0168-1923(03)00140-0

Taylor N. G., Scheible W. R., Cutler S., Somerville C. R., Turner S. R. 1999. The irregularxylem 3 locus of Arabidopsis encodes a cellulose synthase required for secondary cell wall synthesis. The Plant Cell, 11 (5): 769-780 http://dx.doi.org/10.1105/tpc.11.5.769 
Verma V., Worland A. J., Savers E. J., Fish L., Caligari P. D. S., Snape J. W. 2005. Identification and characterization of quantitative trait loci related to lodging resistance and associated traits in bread wheat. Plant Breeding, 124 (3): 234-241

Walter H. K., Lieth H. 1967. Climate diagram world atlas. Jena, Germany (in German) http://dx.doi.org/10.1111/j.1439-0523.2005.01070.x

Yang S. M., Xie L., Zheng S. L., Li J., Yuan J. C. 2009. Effects of $\mathrm{N}$ rate and transplanting density on physical and chemical characteristics and lodging resistance of culms in hybrid rice. Acta Agronomica Sinica, 35: 93-103 http://dx.doi.org/10.3724/SP.J.1006.2009.00093

Zuber U., Winzeler H., Messmer M. M., Keller M., Keller B., Schmid J. E., Stamp P. 1999. Morphological traits associated with lodging resistance of spring wheat (Triticum aestivum L.). Journal of Agronomy and Crop Science, 182 (1): 17-24 http://dx.doi.org/10.1046/j.1439-037x.1999.00251.x

ISSN 1392-3196 / e-ISSN 2335-8947

Zemdirbyste-Agriculture, vol. 102, No. 3 (2015), p. 273-280

DOI $10.13080 / \mathrm{z}-\mathrm{a} .2015 .102 .035$

\title{
Vasarinių miežių pasẻlio struktūra kaip pasėlio išgulimo rizikos rodiklis
}

\author{
P. Matušinsky, I. Svobodová, P. Míša \\ Agrotest Fyto Ltd, Čekijos Respublika
}

\section{Santrauka}

Lauko eksperimentai 2012-2014 m. buvo vykdyti Kromeriže, Čekijos Respublikoje. Bandymų metu tirtos įvairios sèjos ir tręšimo azotu normos. Tyrimo tikslas - nustatyti pasèlio struktūros rodiklius, kurie leistų įvertinti pasèlio išgulimo riziką jau ankstyvuoju vasarinių miežių augimo tarpsniu (BBCH 39). Pasèlio išgulimui didelès įtakos turèjo ir metai, ir tręšimo azotu normos. Didesnès azoto trą̌şu normos žymiai padidino pasėlio išgulimą. Didesnès trąšų normos lèmè didesnị ūglių biomasès svorị, didesnị augalų aukštị ir mažesnes šaknis. Baltymų kiekiui nukultuose grūduose didelès įtakos taip pat turèjo metai ir azoto trąšų normos. Dèl didesnių azoto trąšų normų grūduose padidejo baltymų kiekis. Sejjos tankumas neturèjo ịtakos nei pasèlio išgulimui, nei baltymų kiekiui grūduose. Derliui turèjo ịtakos tik metai. Reikšmingi pasėlio išgulimo rodikliai yra ankstyvaisiais augimo tarpsniais padidèję ūglių biomasès svoris ir augalų aukštis. Koreliacija tarp pasèlio išgulimo, ūglių biomasès ir augalų aukščio buvo didesnè nei 0,5 ir esminè $(P=0,000)$.

Reikšminiai žodžiai: agrotechnika, augalų tankumas, Hordeum vulgare, tręšimas azotu. 